\title{
Involvement of a calcium-dependent dephosphorylation of BAD associated with the localization of Trpc-1 within lipid rafts in 7-ketocholesterol-induced THP-1 cell apoptosis
}

\author{
A Berthier ${ }^{1}$, S Lemaire-Ewing ${ }^{1}$, C Prunet ${ }^{1}$, S Monier ${ }^{1}$, A Athias ${ }^{1}$, \\ G Bessède ${ }^{1}$, J-P Pais de Barros ${ }^{1}$, A Laubriet $^{2}$, P Gambert $^{1}$, \\ G Lizard ${ }^{1}$ and D Néel ${ }^{*, 1}$ \\ 1 Inserm U498 'Métabolisme des lipoprotéines humaines et interactions \\ vasculaires'/IFR 100 Inserm, CHU/Hôpital du Bocage, BP77908, 21079 Dijon \\ Cedex, France \\ ${ }^{2}$ Laboratoire de Physiopathologie et Pharmacologie Cardio-vasculaires \\ Expérimentales/IFR 100 Inserm, Facultés de Médecine et Pharmacie, 7, Bd \\ Jeanne D'Arc, 21033 Dijon Cedex, France \\ * Corresponding author: D Néel, Inserm U498 (Métabolisme des lipoprotéines \\ humaines et interactions vasculaires), Laboratoire de Biochimie Médicale, \\ CHU/Hôpital du bocage 2Bd Maréchal de Lattre de Tassigny BP 77908, 21079 \\ Dijon Cedex, France. Tel: +33-3-80-29-50-03; Fax: + 33-3-80-29-36-61; \\ E-mail: dominique.neel@chu-dijon.fr
}

Received 17.12.03; revised 16.2.04; accepted 18.2.04; published online 23.4.04 Edited by $S$ Orrenius

\begin{abstract}
7-Ketocholesterol is a component of oxidized LDL, which plays a central role in atherosclerosis. It is a potent inducer of cell death towards a wide number of cells involved in atherosclerosis. In this study, it is reported that 7-ketocholesterol treatment induces an increase of cytosolic-free $\mathrm{Ca}^{2+}$ in THP-1 monocytic cells. This increase is correlated with the induction of cytotoxicity as suggested from experiments using the $\mathrm{Ca}^{2+}$ channel blockers verapamil and nifedipine. This 7-ketocholesterol-induced apoptosis appears to be associated with the dephosphorylation of serine 75 and serine 99 of the proapoptotic protein Bcl-2 antagonist of cell death (BAD). We demonstrated that this dephosphorylation results mainly from the activation of calciumdependent phosphatase calcineurin by the oxysterol-induced increase in $\mathrm{Ca}^{2+}$. Moreover, this $\mathrm{Ca}^{2+}$ increase appears related to the incorporation of 7-ketocholesterol into lipid raft domains of the plasma membrane, followed by the translocation of transient receptor potential calcium channel 1 , a component of the store operated $\mathrm{Ca}^{2+}$ entry channel, to rafts.

Cell Death and Differentiation (2004) 11, 897-905.

doi:10.1038/sj.cdd. 4401434

Published online 23 April 2004
\end{abstract}

Keywords: oxysterols; calcineurin; atherosclerosis; monocyte; lipid raft domains

Abbreviations: BAD, Bcl-2 antagonist of cell death; LRD, lipid raft domain; TRPC-1, transient receptor potential calcium channel 1; SOC, store operated calcium; 7-keto, 7-ketocholesterol; CsA, cyclosporin A; Nif, nifedipine; Vera, verapamil

\section{Introduction}

Oxidized low-density lipoproteins (oxLDL), which are a complex mixture of various components comprised of lipid hydroperoxides, aldehydes, and cholesterol oxidation products (oxysterols), play an important role in the development of atherosclerosis. ${ }^{1}$ It has been shown that oxysterols mediate the early events in atherosclerosis induced by oxLDL, such as the expression of adhesion molecules, the production of various proinflammatory cytokines, ${ }^{2}$ and cytotoxicity towards various cell types, including those found in the vascular wall, that is, vascular smooth muscle cells (SMC), endothelial cells, macrophages/monocytes, and fibroblasts. ${ }^{3-6}$ This cytotoxicity has been partly attributed to the induction of apoptosis. So apoptosis appears to be an important event occurring during atherosclerosis. It is probably involved in the formation of the initial lesions, where endothelial cells could be killed by oxLDL, or later, when in progressing lesions, the destruction of foam cells induces the formation of the lipid core. Due to this fundamental role of apoptosis in atherosclerosis, it is important to identify the molecules susceptible in initiating this form of cell death and to characterize their mechanisms. Among these proapoptotic molecules, oxysterols probably play a key role in the initiation and the development of atherosclerosis. Indeed, some of them are potent inducers of apoptosis in tumor and normal cells, especially monocytes ${ }^{5}$ and those found in the vascular wall, that is, SMC, endothelial cells, and fibroblasts. ${ }^{3,4,6}$ However, of the 60 oxysterols identified, only a few of them are cytotoxic, including $7 \beta$-hydroxycholesterol and 7-ketocholesterol. ${ }^{7}$ Oxysterolinduced apoptosis is characterized by well-known postmitochondrial events, such as the loss of mitochondrial transmembrane potential $\left(\Delta \Psi_{\mathrm{m}}\right)$, the release of cytochrome $c$ into the cytosol, caspase- 9 and -3 activation, and PARP degradation. $^{8}$ Of note, 25-hydroxycholesterol is not cytotoxic to monocytes, whereas cytotoxic activities were established in macrophages and vascular SMC, underlying the complexity of the biological activities of oxysterols. ${ }^{9,10}$ Recently, it has been shown in monocyte-like cells that oxysterol-mediated cell death resulted in the inability of ACAT to esterify these compounds. ${ }^{11}$ However, it is not clear how oxysterols, and particularly 7-ketocholesterol, induce apoptosis in these and other vascular cells. Therefore, it is important to identify the premitochondrial events triggered by 7 -ketocholesterol and to elucidate the differences observed between oxysterols.

$\mathrm{Ca}^{2+}$ mobilization can induce apoptosis by activating $\mathrm{Ca}^{2+}$-dependent proteases, phosphatases, and endonucleases, and by depleting intracellular $\mathrm{Ca}^{2+}$ stores. So, it appears that calcium homeostasis needs to be tightly regulated for cell survival. It has been recently reported that in human aortic SMC, $7 \beta$-hydroxycholesterol-induced apoptosis 
is preceded by $\mathrm{Ca}^{2+}$ oscillations $^{9}$ and 25 -hydroxycholesterolinduced apoptosis is inhibited by the $\mathrm{Ca}^{2+}$ channel blockers verapamil and nifedipine. ${ }^{12}$ Moreover, Wang et al. ${ }^{13}$ recently demonstrated that L-glutamate induced a sustained increase in cytosolic-free $\mathrm{Ca}^{2+}$ leading to the activation of the serinethreonine phosphatase calcineurin (PP2B) and to the subsequent apoptosis of hippocampal neurons by dephosphorylation of the proapoptotic protein $\mathrm{Bcl}-2$ antagonist of cell death (BAD). Indeed BAD, through heterodimerization with the antiapoptotic proteins $\mathrm{Bcl}-2$ and $\mathrm{Bcl}_{-} \mathrm{X}_{\mathrm{L}}{ }^{14}$ triggers apoptosis by inducing the release of mitochondrial cytochrome $c$ and is only active in its dephosphorylated form. The inactive form of human BAD, which remains in the cytosol, is therefore phosphorylated in the following ways:

- On serine 75 and/or 99, establishing an interaction with the 14-3-3 proteins ${ }^{15}$ and is then locked up in the cytoplasm far from the mitochondrial membrane where it could interact with $\mathrm{BCl}-\mathrm{X}_{\mathrm{L}}$.

- On serine 118 in the interaction domain $(\mathrm{BH} 3)$ with $\mathrm{Bcl}-\mathrm{X}_{\mathrm{L}}$, blocking the association between the two proteins. ${ }^{16}$

Phosphorylation of serine 75 , under the control of growth factors, uses the signal pathway ending with protein kinase $A$ $(\mathrm{PKA})^{17}$ or with RSK1, one of the terminal kinases in the MAP kinase pathway. ${ }^{18}$ Phosphorylation of serine 99 is under the control of PI3 kinase - Akt (PKB), ${ }^{19}$ whereas phosphorylation of serine 118 needs the intervention of the MAP kinases and PKA pathways. ${ }^{20}$

In the reported data, we demonstrated for the first time, a mechanism initializing cell death induced by a main cytotoxic oxysterol present in oxLDL. 7-Ketocholesterol treatment of THP-1, a human monocytic cell line, induces modifications in lipid raft domains (LRDs), leading to a sustained increase of cytosolic-free $\mathrm{Ca}^{2+}$ then to calcineurin activation, BAD dephosphorylation, and consequently apoptosis.

\section{Results}

\section{Effect of 7-ketocholesterol on intracellular (cytosolic-free) $\mathrm{Ca}^{2+}$ contents}

In order to demonstrate that 7-ketocholesterol treatment affects the intracellular concentration of calcium, we directly measured $\mathrm{Ca}^{2+}$ contents in THP-1 cells. Treatment of THP-1 cells with 7 -ketocholesterol $(40 \mu \mathrm{g} / \mathrm{ml})$ induced a significant and sustained increase (six-fold compared to control cells) of intracellular calcium content whereas treatment with cholesterol $(40 \mu \mathrm{g} / \mathrm{ml})$ had no effect (Figure 1$)$. A maximum was reached after $8 \mathrm{~h}$ of treatment, which was maintained until propidium iodide (PI) permeable cells appeared (data not shown). On the contrary, ethanol, the oxysterol solvent $(0.04 \%)$, did not induce $\mathrm{Ca}^{2+}$ flux, indicating that the rise in calcium was specific to 7-ketocholesterol treatment (data not shown). Cell treatment with the L-type calcium channel blockers nifedipine $(50 \mu \mathrm{M})$ or verapamil $(100 \mu \mathrm{M})$ induced a significant decrease of free-calcium content in 7-ketocholesterol-treated cells, as measured with Fluo-3, indicating the involvement of L-Type calcium channels in 7-ketocholesterolinduced cytosolic calcium increase (Figure 1).

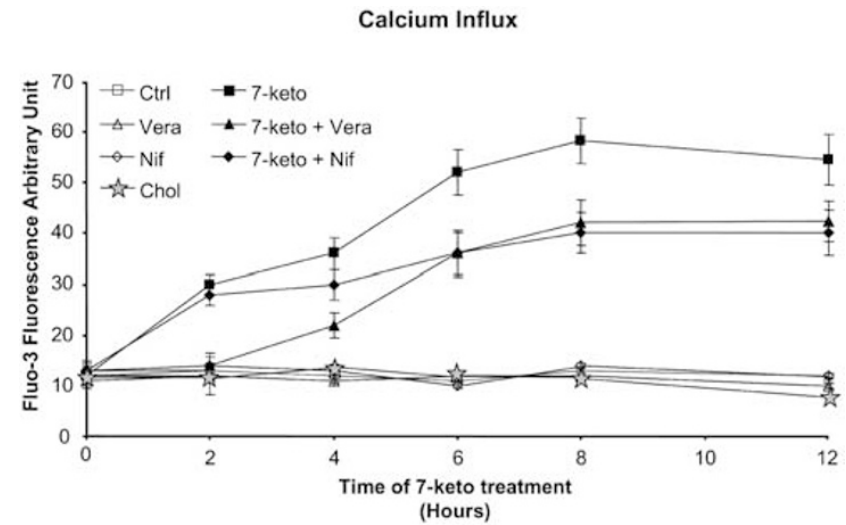

Figure 1 7-Ketocholesterol induces an increase of free intracellular $\mathrm{Ca}^{2+}$ inhibited by L-type channel blockers. THP-1 cells were incubated in the presence of 7-ketocholesterol ( $40 \mu \mathrm{g} / \mathrm{ml}, 7-k e t o)$, with or without nifedipine (50 $\mu \mathrm{mol} / \mathrm{l}$, Nif) or verapamil (100 $\mu \mathrm{mol} / \mathrm{l}$, Vera), in the absence of oxysterol (Ctrl) or in presence of cholesterol ( $40 \mu \mathrm{g} / \mathrm{ml}$, Chol). After different incubation times, cells were loaded with fluo-3/AM and the dye fluorescence was measured by flow cytometry. Each fluorescent data point is normalized to the maximal fluo-3 fluorescence induced in cells treated with ionomycin $(2 \mu \mathrm{mol} / /)$. Data are the mean values \pm S.D. $(n=5)$

\section{7-Ketocholesterol-induced cytotoxicity: a calcium-dependent apoptosis}

To investigate if the 7-ketocholesterol-induced $\mathrm{Ca}^{2+}$ increase correlated with the induction of apoptosis, nifedipine $(50 \mu \mathrm{M})$ and verapamil $(100 \mu \mathrm{M})$ were individually added to the 7ketocholesterol treatment. Treatment of THP-1 cells with 7ketocholesterol induced cell death as assayed by the PI staining viability test, and this death was mainly apoptosis as assessed by measurement of Hoechst 33342 staining or active caspase-3 immunocytochemistry (Figure 2), whereas cholesterol treatment did not induce THP-1 cell death (data not shown). Interestingly, the number of dead cells measured with PI was slightly higher than cells exhibiting typical morphological features of apoptosis such as condensed and/or fragmented nuclei, which were identified after staining with Hoechst 33342. However, no difference was detected between the number of cells permeable to $\mathrm{PI}$ and the number of cells with activated caspase-3 (cleaved caspase-3), showing that 7-ketocholesterol-induced apoptosis is a complex mechanism degenerating to secondary necrosis. ${ }^{21}$

When added to the 7-ketocholesterol treatment, nifedipine and verapamil significantly reduced cell death and apoptosis. Indeed, these L-type channel blockers induced a significant decrease in the proportion of dead cells: a $45 \%$ decrease $18 \mathrm{~h}$ after nifedipine treatment and a $40 \%$ decrease $18 \mathrm{~h}$ after verapamil treatment. In the same way, apoptosis was partially inhibited by nifedipine and verapamil with a 37 and $45 \%$ decrease, respectively, when quantified with Hoechst 33342 (Figure 2). These L-Type channel blockers also inhibited the number of cells with active caspase- 3 (37 and $40 \%$ inhibition with nifedipine and verapamil, respectively). Besides immunocytochemistry, Western blot analyses were performed to confirm the cleavage of caspase-3 (data not shown). However, the effects of these channel blockers diminished after $24 \mathrm{~h}$ of treatment. The incomplete inhibition of the 7-ketocholesterol-induced $\mathrm{Ca}^{2+}$ increase by verapamil or 


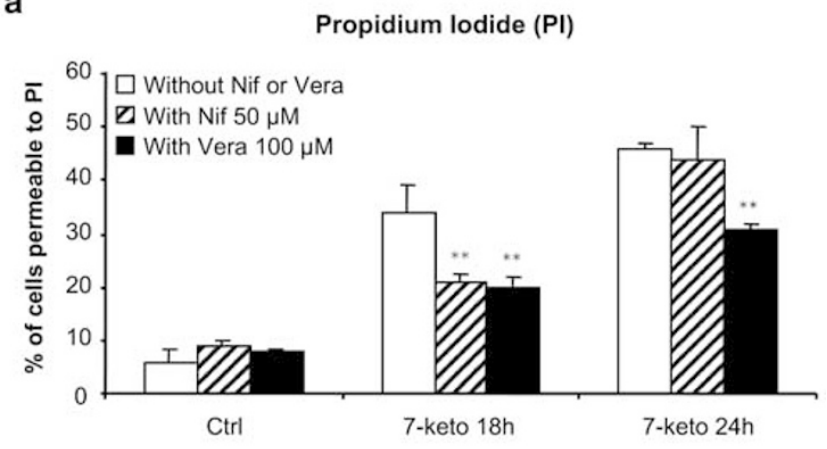

b

Hoechst 33342

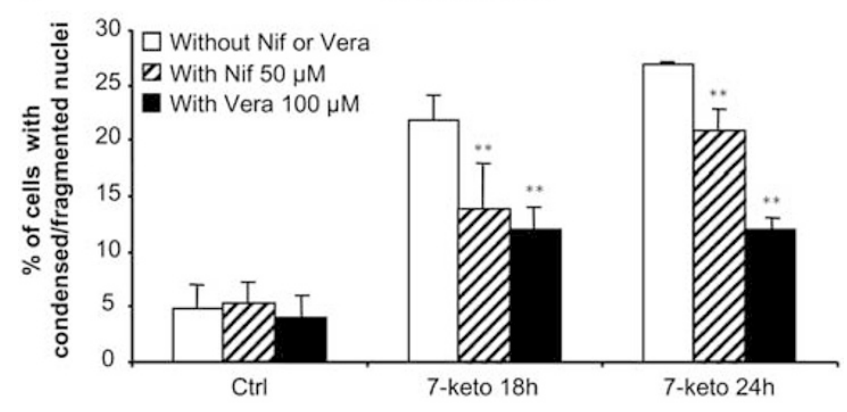

C

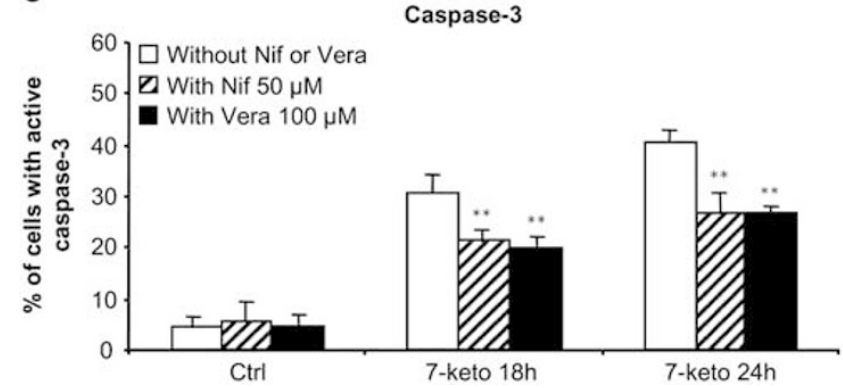

Figure $2 \mathrm{Ca}^{2+}$ channel blockers inhibit apoptosis induced by 7-ketocholesterol. THP-1 cells were either untreated (Ctrl) or incubated with verapamil $(100 \mu \mathrm{mol} / \mathrm{l})$, nifedipine $(50 \mu \mathrm{mol} / \mathrm{l})$ alone or in association with 7 -ketocholesterol for 18 or $24 \mathrm{~h}$. (a) Cell permeability to PI was quantified by flow cytometry. After treatment, cells were incubated with PI and 10000 cells were subjected to flow cytometry analysis. Results represent the mean values \pm S.D. $(n=5)$. (b) Microscopic quantification of cells with fragmented and/or condensed nuclei was performed using Hoechst 33342 . After treatment, cell nuclei were observed by fluorescence microscopy after staining with Hoechst 33342 and the percentage of apoptotic cells was determined. Data are the mean values \pm S.D. $(n=5)$. (c) Immunocytochemistry analysis of cells with active caspase-3 was performed after staining with an antibody recognizing only the active form of caspase-3. After treatment, cells were observed and the percentage of active caspase- 3 cells was determined. Data are the mean values \pm S.D. $(n=5)$. For all experiments, ${ }^{* *} P<0.05$

nifedipine could suggest the involvement of (a) calcium source(s) insensitive(s) to these drugs.

\section{7-Ketocholesterol treatment of THP-1 cells induces BAD dephosphorylation}

BAD is a proapoptotic protein, which in its dephosphorylated form induces the mitochondrial apoptotic pathway by opening the megachannel through its interaction with $\mathrm{Bcl}-2$ or $\mathrm{Bcl}-\mathrm{X}_{\mathrm{L}}{ }^{14}$

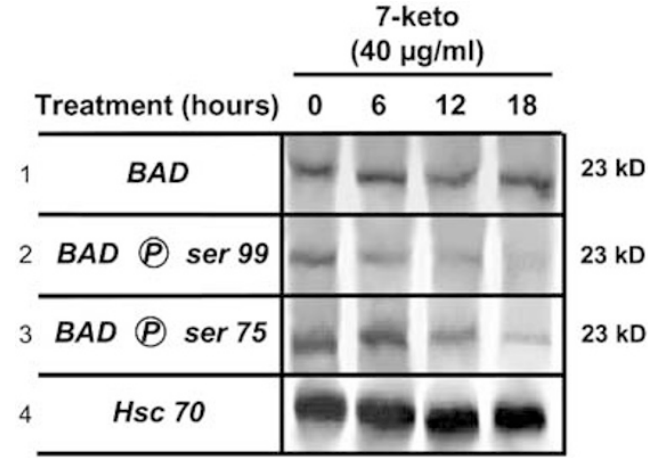

Figure 3 7-Ketocholesterol induces BAD dephosphorylation. After 7-ketocholesterol treatment for 6,12 , and $18 \mathrm{~h}$, treated or untreated THP-1 cell extracts were collected, subjected to SDS-PAGE and immunoblotted with BAD antibody (lane 1), phospho-BAD ser 99 antibody (lane 2), phospho-BAD ser 75 antibody (lane 3) and, in order to verify protein quantities, Hsc-70 antibody (lane 4). The blot is representative of three similar experiments

The inactive form of BAD, which remains in the cytoplasm, is phosphorylated. After treatment with 7-ketocholesterol, BAD, which in control cells was phosphorylated on serine 75 and serine 99, was dephosphorylated (Figure 3). Western blot analyses performed with antibodies specific to phospho-BAD ser 75 or phospho-BAD ser 99 revealed a significant dephosphorylation of BAD, which first appeared no later than $6 \mathrm{~h}$ after the beginning of treatment. However, dephosphorylation at serine 75 was delayed (18h) and incomplete, whereas dephosphorylation at serine 99 was complete in cells treated for $18 \mathrm{~h}$ with 7-ketocholesterol. The phosphorylation state of BAD on serine 118 was also investigated, but we were unable to show, by Western blot analysis, that BAD was phosphorylated on this serine residue in either untreated or 7ketocholesterol-treated cells (data not shown). Western blot analyses performed with an antibody interacting with all forms of BAD showed that the decrease of the phosphorylated forms of BAD after oxysterol treatment was not related to a significant alteration of the amount of BAD protein, but rather to the dephosphorylation of BAD (Figure 3).

\section{7-Ketocholesterol-induced apoptosis is calcineurin-dependent}

Since it has been shown that a sustained increase in cytosolicfree calcium could lead to the activation of the serine/ threonine phosphatase calcineurin (PP2B) and to subsequent apoptosis in susceptible cells, ${ }^{13}$ we explored the possibility that, in our model, PP2B might be activated. FK506 and cyclosporin $A$ (CsA), drugs that indirectly inhibit calcineurin through their effects on peptidyl-propyl-cis trans isomerase, were used to investigate the possibility that calcineurin could mediate the 7-ketocholesterol-induced apoptosis of THP-1 cells. Figure 4 shows that the addition of either CsA $(2 \mu \mathrm{mol} / \mathrm{l})$ or FK506 $(1 \mu \mathrm{mol} / \mathrm{l})$ to the cell culture significantly decreases, particularly after $18 \mathrm{~h}$ of 7 -ketocholesterol treatment, in the number of dead cells by $35 \%$ (measured by PI staining), the number of apoptotic cells by $45 \%$ (quantified with Hoechst 33342 ), as well as the number of cells with active caspase-3 by $40 \%$ (Figures $4 a-c$ ). Western blot analyses of caspase-3 were also performed in order to confirm the activation of 
a

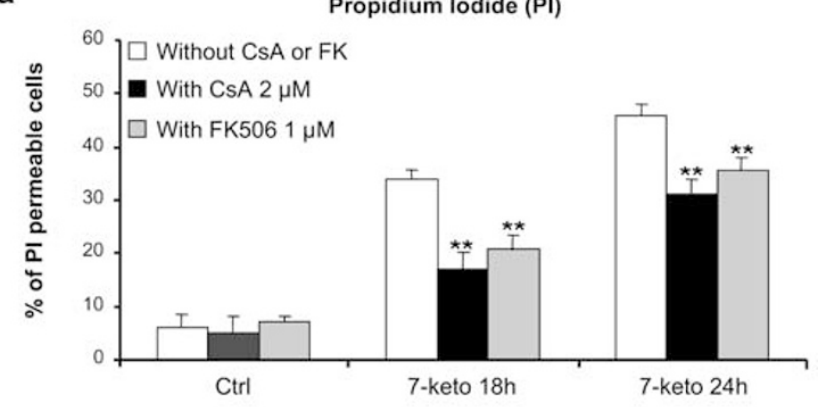

b

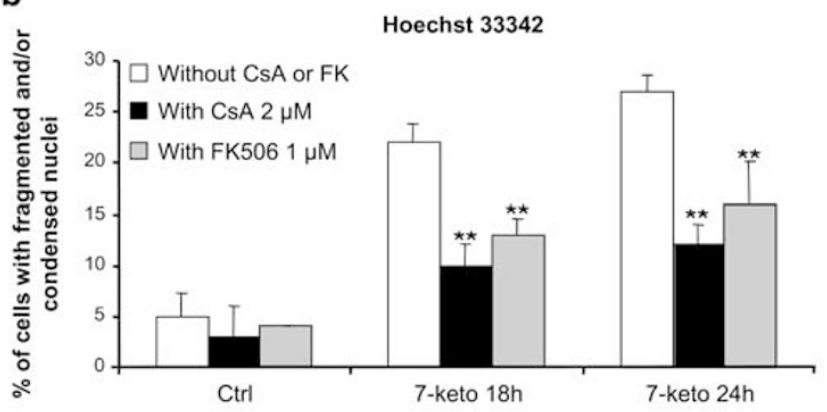

C

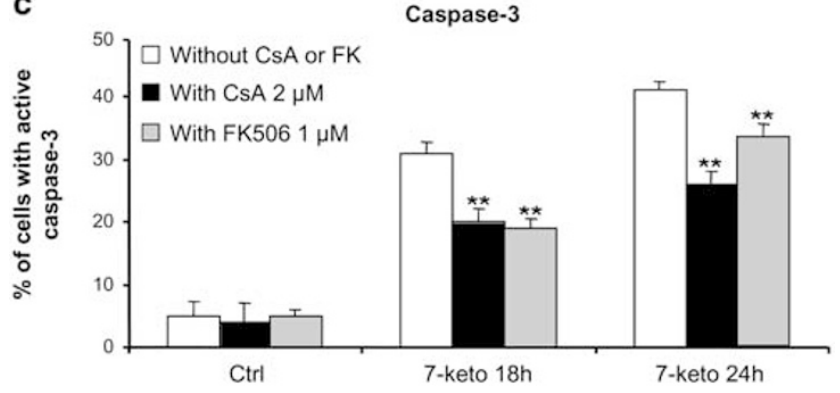

Figure 4 CsA and FK506 inhibit 7-ketocholesterol-induced apoptosis. THP-1 cells were either untreated (Ctrl), treated with CsA (CsA, $2 \mu \mathrm{mol} / \mathrm{l})$ or with FK506 $(1 \mu \mathrm{mol} / \mathrm{l})$, or treated with 7 -ketocholesterol (7-keto) for 18 and $24 \mathrm{~h}$ alone or in association with CsA $(2 \mu \mathrm{mol} / /)$ or FK506 $(1 \mu \mathrm{mol} / /)$. (a) Cell permeability to PI was quantified by flow cytometry. After treatment, cells were incubated with PI and 10000 cells were subjected to flow cytometry analysis. Results represent the mean values \pm S.D. $(n=5)$. (b) Microscopic quantification of apoptotic cells was performed using Hoechst 33342. After treatment, cell nuclei were observed by fluorescence microscopy after staining with Hoechst 33342 and the percentage of apoptotic cells was determined. Data are the mean values \pm S.D. $(n=5)$. (c) Immunocytochemistry analysis of cells with active caspase-3 was performed after staining with an antibody recognizing only the active form of caspase-3. After treatment, cells were observed and the percentage of active caspase- 3 cells was determined. Data are the mean values \pm S.D. $(n=5)$. For all experiments, ${ }^{\star *} P<0.05$

caspase- 3 by cleavage (data not shown). As it has been reported that CsA could have partial cytoprotective effects beyond calcineurin inhibition, due to its binding to mitochondrial cyclophilin and its interference with mitochondrial transition pore opening, it is interesting to note that the effects of FK506 could not be explained by this alternative mechanism and that there was no significant difference between CsA or FK506-treated cells for all parameters studied.

Therefore, the implication of calcineurin in BAD dephosphorylation was only determined through the use of CsA. As Wang et al. ${ }^{13}$ demonstrated that calcineurin could induce the

\begin{tabular}{|c|c|c|c|c|c|c|c|c|}
\hline \multirow[b]{3}{*}{ Blot } & \multicolumn{8}{|c|}{ Anti-BAD IP } \\
\hline & \multicolumn{8}{|c|}{ Treatment } \\
\hline & Ctrl & Csa & $\begin{array}{c}\text { 7-keto } \\
6 \mathrm{~h}\end{array}$ & $\begin{array}{l}\text { 7.keto } 6 \mathrm{~h} \\
+ \text { Csa }\end{array}$ & $\begin{array}{c}\text { 7-keto } \\
12 \mathrm{~h}\end{array}$ & $\begin{array}{c}7-\text {-keto } 12 \mathrm{~h} \\
+ \text { Csa }\end{array}$ & $\begin{array}{c}\text { 7.keto } \\
18 \mathrm{~h}\end{array}$ & $\begin{array}{l}\text { 7-keto } 18 \mathrm{~h} \\
+ \text { Csa }\end{array}$ \\
\hline Calcineurin & 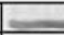 & $=$ & 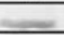 & $=$ & 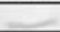 & $=$ & 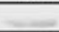 & $x^{2}$ \\
\hline$B A D$ & 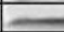 & 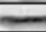 & 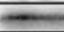 & - & $=$ & 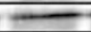 & & 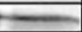 \\
\hline
\end{tabular}

Figure 5 7-Ketocholesterol induces the dissociation of $B A D$ from calcineurin. THP-1 cells were either untreated (Ctrl), treated with CsA $(2 \mu \mathrm{mol} / \mathrm{l})$, or treated with 7-ketocholesterol (7-keto) for 6, 12, and $18 \mathrm{~h}$ alone or in association with CsA $(2 \mu \mathrm{mol} / \mathrm{l})$. After treatment, anti-BAD immunoprecipitates were collected, subjected to SDS-PAGE, and immunoblotted with antibodies specific for the A subunit of calcineurin (lane 1) or BAD (lane 2). The blot is representative of three similar experiments

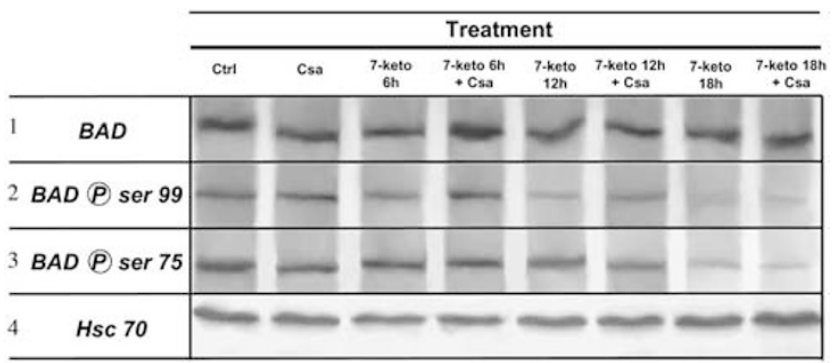

Figure 6 CsA inhibits 7-ketocholesterol-induced apoptosis through the inhibition of BAD dephosphorylation. THP-1 cells were either untreated (Ctrl), treated with CsA ( $2 \mu \mathrm{mol} / \mathrm{l})$, or treated with 7-ketocholesterol (7-keto) for 6, 12, and $18 \mathrm{~h}$ alone or in association with CsA $(2 \mu \mathrm{mol} / /)$, and cell extracts were collected. Lysates were subjected to SDS-PAGE and immunoblot analysis with antibodies against BAD (lane 1), phospho-BAD ser 99 (lane 2), phospho-BAD ser 75 (lane 3), and Hsc-70 (lane 4) was performed

dephosphorylation of BAD, we tested this possibility. Coimmunoprecipation experiments revealed that calcineurin is complexed with BAD in THP-1 control cells. Interestingly, little calcineurin was complexed with BAD after induction of dephosphorylation by 7-ketocholesterol (Figure 5). Thus, calcineurin appears to exist in a complex containing BAD before, but not after, $\mathrm{Ca}^{2+}$ influx as described in HCT 116 cells. ${ }^{13}$ To confirm the involvement of PP2B in 7-ketocholesterol-induced apoptosis, CsA was used to investigate whether it could abolish the dissociation of BAD-calcineurin complexes and, in consequence, inhibit BAD dephosphorylation. To test this hypothesis, we first performed co-immunoprecipitaion experiments in THP-1 cells treated with 7-ketocholesterol and CsA. Figure 5 shows that CsA treatment significantly decreases the dissociation of BAD-calcineurin complexes, as early as $6 \mathrm{~h}$ after treatment. Moreover, Western blot analyses performed with phospho-BAD ser 75- and phospho-BAD ser 99-specific antibodies showed that the addition of CsA to the 7-ketocholesterol treatment inhibited BAD dephosphorylation, particularly at serine 99, confirming the involvement of calcineurin in BAD dephosphorylation (Figure 6). However, the inhibition of dephosphorylation was not permanent at serine 99 after $18 \mathrm{~h}$ of treatment and was not seen at serine 75 , suggesting that another phosphatase or alternative $\mathrm{Ca}^{2+}$. initiated cell death pathway(s) could also be implicated in oxysterol-induced BAD dephosphorylation. ${ }^{22,23}$

Moreover, as mitochondria depolarization and cytochrome $c$ release from mitochondria are key events in the mitochondrial apoptotic pathway induced by cytotoxic oxysterols, we wondered if CsA could inhibit such mechanisms. Transmem- 


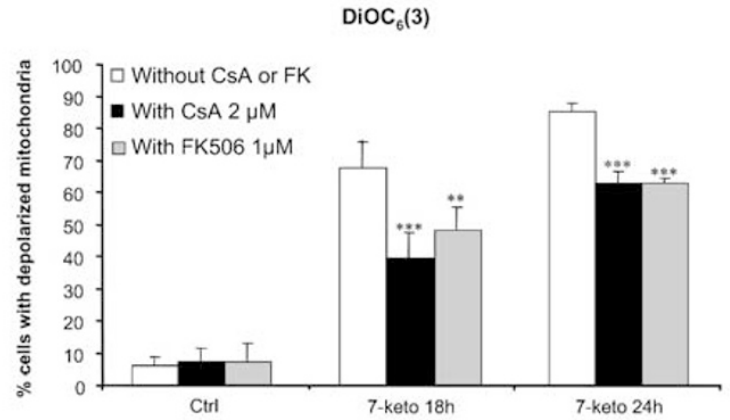

b

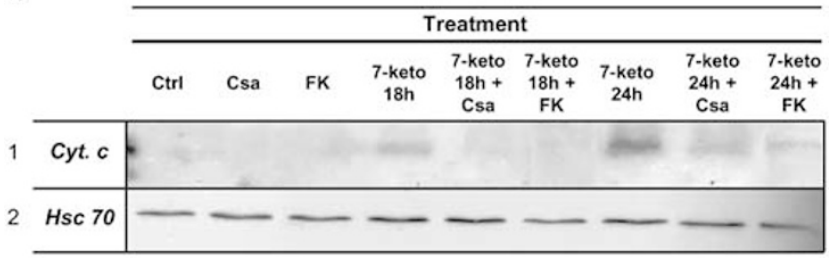

Figure 7 CsA or FK506 treatment of THP-1 cells inhibits cytochrome c release and mitochondrial depolarization induced by 7-ketocholesterol. (a) Transmembrane mitochondrial potential was measured by flow cytometry using the $\mathrm{DiOC}_{6}(3)$ dye. After the incubation period, fluorescence associated with $\mathrm{DiOC}_{6}(3)$ was measured by flow cytometry and 10000 cells were analyzed for each assay. Results represent the mean values \pm S.D. $\left(n=5,{ }^{* *} P<0.05,{ }^{* * *} P<0.01\right)$. (b) THP-1 cells were either untreated (Ctr)), treated with CsA $(2 \mu \mathrm{mol} / \mathrm{l})$ or with FK506 (FK, $1 \mu \mathrm{mol} / \mathrm{l})$, or treated with 7-ketocholesterol (7-keto) for 18 and $24 \mathrm{~h}$ alone or in association with CsA or FK506, and cytosol fractions were collected. Subcellular fractions were subjected to SDS-PAGE and immunoblot analysis with antibodies against cytochrome $c$ (lane 1) and Hsc-70 (lane 2) were performed

brane mitochondrial potential analysis and cytochrome $c$ Western blots were performed, and we showed that CsA dramatically reduced the number of cells with depolarized mitochondria and the cytochrome $c$ release in agreement with the involvement of calcineurin in 7-ketocholesterol-induced apoptosis. As CsA has the ability to prevent mitochondrial permeability transition without involvement of $B A D$, the experiments were also performed with FK506 which cannot prevent mitochondrial permeability (Figure 7). These results showing no significant differences between the protective effects of CSA and FK506 support the involvement of a BAD mediated pathway in 7-ketocholesterol induced apoptosis.

\section{7-Ketocholesterol treatment of THP-1 cells induces translocation into rafts of Trpc-1, a component of the store operated $\mathrm{Ca}^{2+}$ entry channel}

As Trpc-1 can participate in the formation of L-type calcium channel $^{24}$ and has been functionally localized in LRDs of the plasma membrane,${ }^{25}$ we wondered whether 7-ketocholesterol could modify the localization of Trpc-1 protein and raft composition. As shown in Figure 8 in untreated cells, Trpc-1 was exclusively found in nonraft structures (high-density fractions), whereas treatment of THP-1 cells with $40 \mu \mathrm{g} / \mathrm{ml} 7$ ketocholesterol induced the translocation of Trpc-1 into LRDs (light-density fractions rich in cholesterol and sphingomyelin). Moreover, in these treated cells, 7-ketocholesterol is incorpo- rated in the LRDs as demonstrated by lipid analysis. Interestingly, treatment of THP-1 cells with $40 \mu \mathrm{g} / \mathrm{ml}$ of cholesterol did not induce relocalization of Trpc-1 into lipid raft and no significant change in the cholesterol content of raft was observed (data not shown).

\section{Discussion}

Among oxysterols, a significant amount of 7-ketocholesterol is present in the plasma and in atherosclerotic lesions. This oxysterol, whose concentration used in this study is in the range of levels measured in the plasma of subjects after a meal rich in fat ${ }^{26}$ and in rabbits that are fed a cholesterol-rich diet, $^{27}$ induces a form of cell death with apoptotic features such as mitochondrial depolarization, cytochrome $c$ release into the cytosol, caspase- 9 and -3 activation, PARP degradation, and condensation/fragmentation of the nuclei. ${ }^{7,8} \mathrm{How}-$ ever, the mechanisms prior to the involvement of mitochondria are not well known. In this study, we elucidated, at least in part, the events by which 7-ketocholesterol induces mitochondria dysfunction and, consequently, apoptosis in the monocytic cell line THP-1. One of the first steps of the phenomenon is the sustained increase of cytosolic-free calcium contents occurring in the hours following the treatment with 7-ketocholesterol, which was partially inhibited by the L-type calcium channel blockers nifedipine and verapamil. Interestingly, unlike nifedipine, verapamil induces a delay in the increase of calcium levels for $4 \mathrm{~h}$ after 7 -ketocholesterol addition before joining the nifedipine inhibition rate. Recently, it has been demonstrated that the nifedipine treatment of THP-1 cells, which were differentiated into macrophages by phorbol ester, prevented the 25-hydroxycholesterol induction of apoptosis. ${ }^{9}$ It has been reported that 25 -hydroxycholesterol and $7 \beta$-hydroxycholesterol quickly induce $\mathrm{Ca}^{2+}$ oscillations followed by apoptosis in human aortic SMC, which are involved, like monocytic cells, in the genesis of atheroma. ${ }^{10,12}$ However, whereas 25-hydroxycholesterol-induced SMC apoptosis could be inhibited by the $\mathrm{Ca}^{2+}$ channel blockers verapamil and nifedipine, ${ }^{12}$ oxysterol-induced calcium oscillations cannot be inhibited by verapamil. ${ }^{10}$ An increase in cytosolic-free calcium has been previously described in the thapsigargin-induced apoptosis of several cell types, particularly prostatic cancer cells. ${ }^{28-30}$ Thapsigargin (an inhibitor of the endoplasmic reticulum $\mathrm{Ca}^{2+} /$ ATPase) induces an initial depletion of intracellular $\mathrm{Ca}^{2+}$ stores, resulting in $\mathrm{Ca}^{2+}$ oscillations followed by a capacitative entry of extracellular $\mathrm{Ca}^{2+}$, which appears necessary for triggering apoptosis. ${ }^{31}$ The authors demonstrated that thapsigargin-induced apoptosis was initiated by the capacitative entry of calcium and not by early $\mathrm{Ca}^{2+}$ oscillations. As demonstrated in our work, 7-ketocholesterol treatment of THP-1 cells induces a sustained increase of cytosolic-free calcium blocked by verapamil and nifedipine, as seen in thapsigargin-treated prostatic cancer cells, ${ }^{30}$ and consequently apoptosis that can be inhibited by these L-type channel blockers. So these results suggest that 7-ketocholesterol apoptosis is initiated by the sustained elevation of cytosolic calcium content and probably not by early $\mathrm{Ca}^{2+}$ oscillations. Nevertheless, incomplete inhibition of 7-ketocholeserol-induced apoptosis was observed 
a

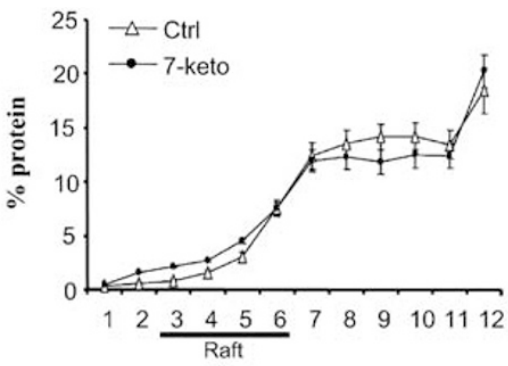

b

Raft Ctrl

Raft 7-keto
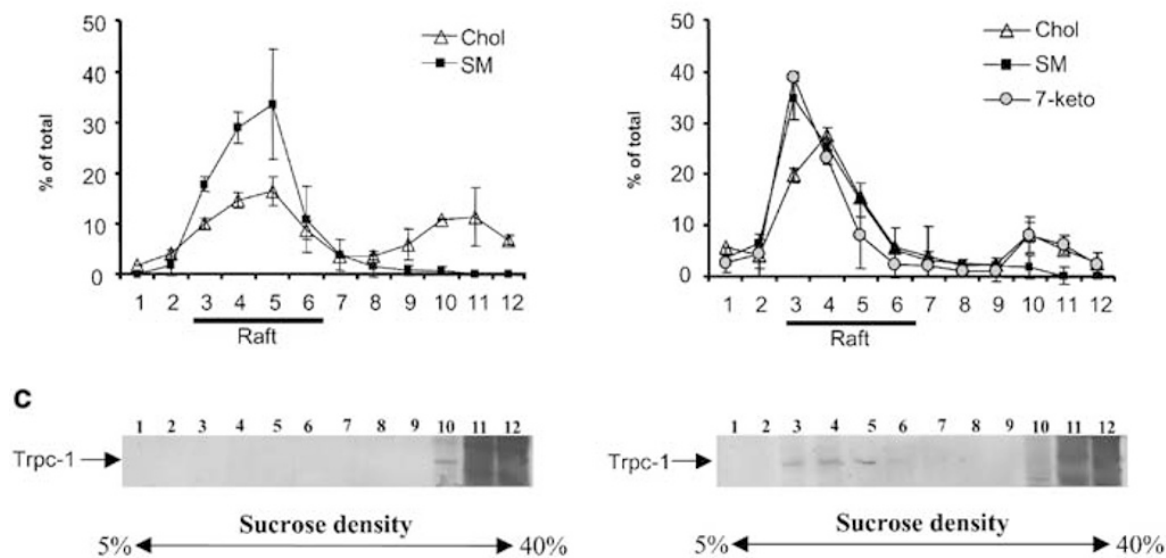

Figure 8 7-Ketocholesterol treatment of THP-1 cells induces relocation of Trpc-1 to lipid rafts. THP-1 cells treated or not with 7-ketocholesterol for $6 \mathrm{~h}$ (7-keto and Ctrl respectively) were lysed in cold Triton X-100 and fractionated on a sucrose density gradient. (a) Distribution of total protein were determined (b) and equal volume aliquots of the fractions were collected and analyzed for shyngomyelin (SM) and cholesterol (Chol) contents (mean of determinations of three representative experiments \pm S.D.) and (c) Western blotted for Trpc-1. Results are representative of two or three independent experiments

with the L-type calcium channel blockers verapamil and nifedipine. Indeed, the blocking of calcium channels appeared to inhibit less than half of either cell death or apoptosis. This observation suggests that the $\mathrm{Ca}^{2+}$ signal could be due to the opening of other calcium channels insensitive to these channel blockers. Thus, these data confirm that cytotoxic oxysterolinduced apoptosis is a complex phenomenon and cells have more than one way to die. However, a rise in intracellular calcium must be a strong candidate for an early step in the signaling pathway of oxysterol-induced apoptosis, as demonstrated by our data and several studies.

Recently, several groups have demonstrated the involvement of a calcineurin-dependent apoptotic cascade following calcium increase in apoptosis induced by thapsigargin or Lglutamate. $^{13,31}$ Indeed, one of the important targets of the cellular increase of $\mathrm{Ca}^{2+}$ is the serine-threonine phosphatase calcineurin (PP2B) and one of calcineurin's main targets is the proapoptotic protein $B A D$, which in its serine 75 (serine 112 in mouse) and/or serine 99 (serine 136 in mouse) phosphorylated species is bound to the 14-3-3 protein in the cytoplasm. ${ }^{15}$ Once dephosphorylated by calcineurin, BAD translocates to the mitochondria where it allows cytochrome $c$ to be released by interacting with the antiapoptotic proteins $\mathrm{Bcl}-2$ and $\mathrm{Bcl}-\mathrm{X}_{\mathrm{L}}{ }^{14}$ In our study, the involvement of calcineurin in the 7-ketocholesterol-induced apoptotic mechanism is clearly underlined through the use of FK506 and CsA, which are calcineurin inhibitors. Each of them strongly reduces apoptosis, as measured by the quantification of cells with fragmented/condensed nuclei and cells with activated caspase-3.

Although calcineurin could also be implicated in the dephosphorylation of transcription factors belonging to the family of the nuclear factor of activated $T$ cells (NFAT), allowing them to regulate inducible genes during the execution of apoptosis by translocation to the nucleus, ${ }^{32,33}$ BAD dephosphorylation appears to be a key event in oxysterolinduced apoptosis as demonstrated by Tombal et al. in thapsigargin-induced apoptosis. ${ }^{31}$ Indeed, Wang et al. ${ }^{13}$ demonstrated the inability of these cells to commit to $\mathrm{Ca}^{2+}$. induced apoptosis by using a cell line transfected with a BAD mutant mimicking a phosphorylated form of the protein. In our study, CsA inhibits the dissociation of BAD-calcineurin complexes and the dephosphorylation of BAD as early as $6 \mathrm{~h}$ after 7-ketocholesterol treatment, although no mitochondrial damage was still observed (data not shown). Moreover, the correlation between the inhibition of BAD dephosphorylation and apoptotic features (mitochondrial depolarization and cytochrome $c$ release) by CsA strongly argues that BAD is one of the main components in the signaling pathway of oxysterolinduced apoptosis. In the same way, our group demonstrated that, like ras/raf-1-stimulated apoptosis, ${ }^{34} 7$-ketocholesterolmediated apoptosis can be inhibited by $\mathrm{Bcl}-2,{ }^{35}$ confirming the probable implication of BAD. The inability of cyclosporin to inhibit BAD dephosphorylation on serine 75 , to maintain the inhibition of 7-ketocholesterol-induced dephosphorylation on serine 99 at $18 \mathrm{~h}$ and to fully abolish apoptosis is in agreement 
with the possible involvement of another phosphatase, which could be protein phosphatase- $1 \alpha$, as suggested by Rebollo's group in their study using a IL2-deprived murine T cell line. ${ }^{22}$ However, the involvement of other proteins regulating caspase activity could not be excluded and are under investigation.

LRDs are spontaneously formed at the plasma membrane and are functionally distinct microdomains that are in a gel phase because of the lateral packing of glycosphingolipids, sphingolipids, and cholesterol within the membrane bilayer. These structures, because of their particular lipid composition, have been proposed to be implicated in cellular signaling mechanisms. ${ }^{36}$ It has been reported that Trpc-1, a component of the store operated $\mathrm{Ca}^{2+}$ entry channel (SOC), is assembled in a signaling complex associated with caveolinscaffolding LRD. ${ }^{25}$ Moreover, the requirement for lipid rafts has been demonstrated in B-cell-receptor-induced $\mathrm{Ca}^{2+}$ influx. ${ }^{37}$ In view of these data, we decided to investigate the possible implication of Trpc-1 and rafts in 7-ketocholesterolinduced signaling. Unlike cholesterol, 7-ketocholesterol induces the translocation of Trpc-1 from nonraft structures to LRD. This particular localization could lead to the opening of $\mathrm{Ca}^{2+}$ channels and consequently to the rise in cytoplasmic $\mathrm{Ca}^{2+}$. Moreover, our results showed that in treated cells, 7ketocholesterol is localized into lipid rafts. However, it remains to be seen how 7-ketocholesterol induces the localization of Trpc-1 into LRD and whether the inhibition of this event could block apoptosis.

Of note, this is the first study describing the events preceding cytochrome $c$ release in the 7-ketocholesterolinduced apoptosis of monocytic cells.

\section{Materials and Methods}

\section{Reagents and antibodies}

The THP-1 cell line was purchased from the American Tissue and Culture Collection (ATCC, Manassas, VA, USA). $\mathrm{DiOC}_{6}(3)$ was purchased from Molecular Probes, Inc. (Eugene, OR, USA). 7-Ketocholesterol, IgePal, ionomycin, PI, fluo-3/AM, dimethylsulfoxide (DMSO), verapamil, nifedipine, pluronic $\mathrm{F}-127$, probenecid, pepstatin $\mathrm{A}$, aprotinin, trypsine inhibitor, leupeptin, phenylmethylsulfonylfluoride (PMSF), Hoechst 33342, and Triton X-100 were purchased from Sigma (Sigma-Aldrich, L'Isles d'AbeauChesnes, France). Anticaspase-3 antibody and CsA were purchased from Biomol (Plymouth Meeting, PA, USA) and FK506 was purchased from Calbiochem (San Diego, CA, USA). The anti-BAD monoclonal antibody, the anti-BAD phospho ser 112 (human ser 75) polyclonal antibody and the anti-BAD phospho ser 136 (human ser 99) polyclonal antibody were purchased from Upstate Biotechnology (Lake Placid, NY, USA), and the anticalcineurin and anticytochrome $c$ monoclonal antibodies and antiactive-caspase-3 polyclonal antibody were purchased from Pharmingen (San Diego, CA, USA). The anti-Hsc 70 polyclonal antibody, protein G-Agarose, and total mouse $\lg G$ were purchased from Santacruz (Santacruz Biotechnologies, USA) and the anti-Trpc-1 was purchased from Alomone Laboratories (Jerusalem, Israel).

\section{Cell culture}

THP-1 cells were grown in suspension in RPMl 1640 with glutamax-I (Gibco, Eragny, France) and antibiotics (100 U/ml penicillin, $100 \mu \mathrm{g} / \mathrm{ml}$ streptomycin) (Gibco), supplemented with 10\% (v/v) heat-inactivated fetal calf serum (Gibco). The THP-1 cells were incubated at $37^{\circ} \mathrm{C}$ under a $5 \%$ $\mathrm{CO}_{2} / 95 \%$ air atmosphere.

\section{Cell treatment}

For all experiments, a 7-ketocholesterol stock solution was prepared at a concentration of $800 \mu \mathrm{g} / \mathrm{ml}$ as previously described. ${ }^{6}{ }^{7-K e t o c h o l e s t e r o l ~}$ was added to the culture medium for a final concentration of $40 \mu \mathrm{g} / \mathrm{ml}$. This oxysterol concentration is in the range of levels measured in human plasma after a meal rich in fat. ${ }^{26}$ Nifedipine and verapamil, two L-type calcium channel inhibitors, were added to the culture medium at a final concentration of 50 and $100 \mu \mathrm{mol} / /$, respectively. The calcineurin inhibitors CsA and FK506 were used at a final concentration of 2 and $1 \mu \mathrm{mol} / \mathrm{l}$, respectively. In all experiments, nifedipine, verapamil, CsA, and FK506 were introduced in the culture medium $15 \mathrm{~min}$ before 7 -ketocholesterol.

\section{Determination of cell permeability with PI}

Cell permeability was determined with $\mathrm{PI}\left(\lambda \mathrm{Ex}_{\max }: 540 \mathrm{~nm}, \lambda \mathrm{Em}_{\max }\right.$ : $625 \mathrm{~nm}$ ), which only stains dead cells. ${ }^{38}$ The red fluorescence was immediately quantified on a Galaxy flow cytometer (Partec, Münster, Germany) at excitation and emission wavelengths of 488 and $585 / 42 \mathrm{~nm}$, respectively. For each sample, 10000 cells were acquired and the data were analyzed with Flomax software (Partec, Münster, Germany).

\section{Characterization of nuclear morphology by staining with Hoechst 33342}

Nuclear morphology of control and treated cells was studied by fluorescence microscopy after staining with Hoechst 33342 ( $\lambda \mathrm{Ex}_{\mathrm{max}}$ : $346 \mathrm{~nm}, \lambda \mathrm{Em}_{\text {max }}: 420 \mathrm{~nm}$ ) used at $10 \mu \mathrm{g} / \mathrm{ml}$. The morphological aspect of cell deposits, applied to glass slides by cytocentrifugation with a cytospin 4 centrifuge (Shandon, Cheshire, UK), was observed with an Axioskop light microscope (Zeiss, Jena, Germany) by using UV light excitation. In total, 300 cells were examined for each sample.

\section{Flow cytometric measurement of mitochondrial transmembrane potential $\left(\Delta \Psi_{m}\right)$ with the dye $\mathrm{DiOC}_{6}(3)$}

Variations of the mitochondrial transmembrane potential $\left(\Delta \Psi_{\mathrm{m}}\right)$ were measured with 3,3'-dihexyloxacarbocyanine iodide $\left(\mathrm{DiOC}_{6}(3) ; \lambda \mathrm{Ex}_{\max }\right.$ : $484 \mathrm{~nm}, \lambda \mathrm{Em}_{\max }: 501 \mathrm{~nm}$ ) used at a final concentration of $40 \mathrm{nmol} / \mathrm{l}^{8}$ The flow cytometric analyses were performed on a Galaxy flow cytometer (Partec) and the green fluorescence was collected through a 524/44 nm band pass filter. Fluorescent signals were measured on a logarithmic scale of four decades of log. For each sample, 10000 cells were acquired and the data were analyzed with Flomax software (Partec).

\section{Flow cytometric measurement of cytosolic calcium with the dye Fluo-3}

THP-1 cells were washed with PBS $(\mathrm{pH}=7.4)$, and then incubated with Fluo-3/AM (6 $\left.\mu \mathrm{mol} / / ; \lambda \mathrm{Ex}_{\text {max }}: 506 \mathrm{~nm}, \lambda \mathrm{Em}_{\max }: 526 \mathrm{~nm}\right)$ for $30 \mathrm{~min}$ at $37^{\circ} \mathrm{C}$ in Hank's balanced salt buffer $(\mathrm{pH}=7.2)$ with Pluronic F-127. After loading, cells were suspended in HEPES buffer $(\mathrm{pH}=7.4)$ supplemented with probenecid $(5 \mathrm{mmol} / \mathrm{l})$ in order to prevent leakage of the dye. ${ }^{39}$ Fluorescence was measured by flow cytometry with a Galaxy flow 
cytometer (Partec) using a 524/44 nm band pass filter. For each sample, events were acquired for $60 \mathrm{~s}$ and the data were analyzed with Flomax software (Partec).

\section{Identification of the active form of caspase- 3 by immunocytochemistry}

Detection of active caspase-3 was performed on THP-1 cell deposits of 40000 cells applied to silanated glass slides by cytocentrifugation for $5 \mathrm{~min}$ at $300 \times g$ with a cytospin 4 centrifuge and stored at $-20^{\circ} \mathrm{C}$. Immunocytochemistry was performed as previously described. ${ }^{40}$ In total, 300 cells were examined under an Axioskop microscope (Zeiss).

\section{Immunoprecipitation and Western blotting}

For the immunoprecipitation of the BAD protein, cells were suspended in immunoprecipitation buffer $(10 \mathrm{mmol} / / \mathrm{Tris}-\mathrm{HCl}, 140 \mathrm{mmol} / / \mathrm{NaCl}$, and $0.1 \%$. IgePal) containing a mixture of protease inhibitors $(0.1 \mathrm{mmol} / \mathrm{l}$ phenylmethylsulfonylfluoride, $2.5 \mu \mathrm{g} / \mathrm{l}$ aprotinin, $10 \mu \mathrm{g} / \mathrm{l}$ pepstatin $\mathrm{A}$, $2.5 \mu \mathrm{g} / \mathrm{l}$ trypsin inhibitor, and $2.5 \mu \mathrm{g} /$ l leupeptin). After $20 \mathrm{~min}$ of incubation at $4{ }^{\circ} \mathrm{C}$ in the lysis buffer, the cell debris were eliminated by centrifugation for $10 \mathrm{~min}$ at $10000 \times \mathrm{g}$. The resulting supernatant was precleared by adding $1 \mu \mathrm{g}$ of total mouse IgG and $50 \mu \mathrm{l}$ of protein G-Agarose for $30 \mathrm{~min}$. After a $10000 \times g$ centrifugation $\left(4^{\circ} \mathrm{C}, 10 \mathrm{~min}\right)$, the supernatant was collected, adjusted to $500 \mu \mathrm{l}$ in lysis buffer, and incubated overnight at $4^{\circ} \mathrm{C}$ with $10 \mu \mathrm{g}$ of the anti-BAD antibody on a rotating device. After the incubation period, $50 \mu$ l of protein G-Agarose were added and the sample was incubated for $2 \mathrm{~h}$ before collecting the immunoprecipitates by centrifugation at $10000 \times g\left(4^{\circ} \mathrm{C}, 5 \mathrm{~min}\right)$. After washing the pellet four times, the immunoprecipitation extract was suspended in Laemmli's buffer ( $1 \%$ SDS, $1 \mathrm{mmol} / /$ sodium-vanadate, $10 \mathrm{mmol} / / \mathrm{Tris}-\mathrm{HCl}$ ).

Alternatively, cells were resuspended in Ripa lysis buffer containing a mixture of protease and phosphatase inhibitors $(0.1 \mathrm{mmol} / \mathrm{l}$ phenylmethylsulfonylfluoride, $2.5 \mu \mathrm{g} / \mathrm{l}$ aprotinin, $10 \mu \mathrm{g} / \mathrm{l}$ pepstatin A, $2.5 \mu \mathrm{g} / \mathrm{l}$ trypsin inhibitor, $2.5 \mu \mathrm{g} / \mathrm{l}$ leupeptin, and $0.1 \mathrm{mmol} / / \mathrm{Na}$-orthovanadate). After $30 \mathrm{~min}$ of incubation at $4^{\circ} \mathrm{C}$ in the lysis buffer, the cell debris were eliminated by centrifugation for $20 \mathrm{~min}$ at $10000 \times g$ and the supernatant was collected.

Cytochrome $c$ release from mitochondria to the cytosol was investigated by Western blot analysis of THP-1 cells incubated for 12 , 18 , or $24 \mathrm{~h}$ with 7-ketocholesterol alone or in association with cylosporin $\mathrm{A}$ as previously described. ${ }^{40}$

The protein concentrations were measured by using bicinchoninic acid reagent (Pierce, Rockford, IL, USA) according to the method of Smith et al. ${ }^{41}$

In all, $100 \mu \mathrm{g}$ of protein were incubated in loading buffer $(125 \mathrm{mmol} / \mathrm{l}$ Tris- $\mathrm{HCl}, \mathrm{pH}=6.8,10 \% \beta$-mercaptoethanol, $4.6 \% \mathrm{SDS}, 20 \%$ glycerol, $5 \mathrm{~mol} / \mathrm{l}$ urea, and $0.003 \%$ bromophenol blue), boiled for $3 \mathrm{~min}$, separated by SDS-polyacrylamide gel-electrophoresis, and electroblotted onto a polyvinylidine difluoride membrane (BioRad, Ivry sur Seine, France). After blocking nonspecific binding sites for $2 \mathrm{~h}$ at room temperature in TPBS (PBS, $0.1 \%$ Tween-20), the membranes were incubated overnight at $4{ }^{\circ} \mathrm{C}$ with the primary antibody diluted in TPBS. After three 10-min washes with TPBS, the membranes were incubated with horseradish peroxidaseconjugated secondary antibody at a dilution of $1: 2500$ for $1 \mathrm{~h}$ at room temperature and washed three times in TPBS for $10 \mathrm{~min}$. Autoradiography of the immunoblots was performed using an enhanced chemoluminescence detection kit (Amersham, Les Ulis, France). Each experiment was repeated three times with identical results.

\section{Lipid raft microdomain isolation and analysis}

Isolation of lipid raft microdomains was performed as previously described. ${ }^{42}$ Briefly, $10^{8}$ THP-1 cells were washed with ice-cold PBS and lysed in $1 \mathrm{ml}$ of MES buffer ( $25 \mathrm{mM} 2$-( $N$-morpholino)-ethanesulfonic acid, pH 6.5, $150 \mathrm{mM} \mathrm{NaCl}$ ) containing 1\% (w/v) Triton X-100. After $30 \mathrm{~min}$ at $4^{\circ} \mathrm{C}$, cells were further homogenized by 10 strokes of a Dounce homogenizer on ice. Ice-cold MES ( $1 \mathrm{ml}$ ) was added and suspension was mixed with $2 \mathrm{ml}$ of $80 \%(\mathrm{w} / \mathrm{v})$ sucrose in MES. This mixture was subsequently loaded under a linear gradient consisting of $8 \mathrm{ml}$ of $5-40 \%$ sucrose in MBS. All solutions contained the following protease inhibitors: $100 \mu \mathrm{M}$ PMSF; $1 \mu \mathrm{M}$ each of leupeptin, aprotinin, pepstatin A and trypsin inhibitor. Gradients were centrifuged in a Beckman SW41 swinging-rotor at $39000 \mathrm{rpm}$ for $16 \mathrm{~h}$ at $4^{\circ} \mathrm{C}$. In total, 12 fractions of $1 \mathrm{ml}$ each were collected (from top to bottom), vortexed, and stored at $-20^{\circ} \mathrm{C}$ before analysis. The cholesterol and shingomeylin composition of the fractions was used as a marker of raft. Cholesterol and sphingomyelin were assayed using a gas chromatography coupled to mass spectrometry method as previously described. ${ }^{43}$ To determine the localization of Trpc-1 in lipid rafts, $90 \mu$ l of each individual fractions were subjected to SDSpolyacrylamide gel electrophoresis and immunoblotted.

\section{Statistical methods}

Statistical analyses were performed with Statview software (Cary, NC, USA), using a two-way analysis of variance.

\section{Acknowledgements}

This work was supported by the University of Bourgogne, the Institut National de la Santé et de la Recherche Médicale (INSERM) and the Conseil Régional de Bourgogne. We are grateful to Jonathan Ewing for reviewing the English version of this manuscript.

\section{References}

1. Ross R (1993) The pathogenesis of atherosclerosis: a perspective for the 1990s. Nature 362: 801-808

2. Lemaire S, Lizard G, Monier S, Miguet C, Gueldry S, Volot F, Gambert P and Néel D (1998) Different patterns of IL-1 $\beta$ secretion, adhesion molecule expression and apoptosis induction in human endothelial cells treated with $7 \alpha-$ $7 \beta$-hydroxycholesterol, or 7-ketocholesterol. FEBS Lett. 440: 434-439

3. Morel DW, Hessler JR and Chisolm GM (1983) Low density lipoprotein cytotoxicity induced by free radical peroxidation of lipid. J. Lipid Res. 24: 10701076

4. Colles SM, Irwin KC and Chisolm GM (1996) Roles of multiple oxidized LDL lipids in cellular injury: dominance of 7 beta-hydroperoxycholesterol. J. Lipid Res. 37: 2018-2028

5. Christ M, Luu B, Mejia JE, Moosbrugger I and Bischoff P (1993) Apoptosis induced by oxysterols in murine lymphoma cells and in normal thymocytes. Immunology 78: 455-460

6. Lizard G, Moisant M, Cordelet C, Monier S, Gambert P and Lagrost L (1997) Induction of similar features of apoptosis in human and bovine vascular endothelial cells treated by 7-ketocholesterol. J. Pathol. 183: 330-338

7. Lizard G, Deckert V, Dubrez L, Moisant M, Gambert P and Lagrost L (1996) Induction of apoptosis in endothelial cells treated with cholesterol oxides. Am. J. Pathol. 148: 1625-1638

8. Miguet $C$, Monier S, Bettaieb A, Athias A, Bessède G, Laubriet A, Lemaire S, Néel D, Gambert $P$ and Lizard $G$ (2001) Ceramide generation occurring during $7 \beta$-hydroxycholesterol- and 7-ketocholesterol-induced apoptosis is caspase independent and is not required to trigger cell death. Cell Death Differ. 8: 83-99 
9. Rusiñol AE, Yang L, Thewke D, Sankhavaram RP, Kramer MF and Sinenski MS (2000) Isolation of a somatic cell mutant resistant to the induction of apoptosis by oxidized low density lipoprotein. J. Biol. Chem. 275: 7296-7303

10. Ares MPS, Pörn-Ares MI, Moses S, Thyberg J, Juntti-Berggren L, Berggren PO, Hultgardh-Nilsson A, Kallin B and Nilsson J (2000) $7 \beta$-hydroxycholesterol induces $\mathrm{Ca}^{2+}$ oscillations, MAP kinase activation and apoptosis in human aortic smooth muscle cells. Atherosclerosis 153: 23-35

11. Monier S, Samadi M, Prunet C, Denance M, Laubriet A, Athias A, Berthier A Steinmetz $E$, Jürgens $G$, Nègre-Salvayre $A$, Bessède $G$, Lemaire-Ewing $S$, Néel D, Gambert P and Lizard G (2003) Impairment of the cytotoxic and oxidative activities of $7 \beta$-hydroxycholesterol and 7-ketocholesterol by esterification with oleate. Biochem. Biophys. Res. Commun. 303: 814-824

12. Ares MPS, Pörn-Ares MI, Moses S, Thyberg J, Juntti-Berggren L, Berggren PO, Hultgardh-Nilsson A, Diczfalusy U, Kallin B, Björkhem I, Orrenius S and Nilsson $\mathrm{J}$ (1997) $\mathrm{Ca}^{2+}$ channel blockers verapamil and nifedipine inhibit apoptosis induced by 25 -hydroxycholesterol in human aortic smooth cells. J. Lipid Res. 38: 2049-2061

13. Wang HG, Pathan N, Ethell Ml, Krajewski S, Yamaguchi Y, Shibasaki F, McKeon F, Bobo T, Franke TF and Reed JC (1999) $\mathrm{Ca}^{2+}$ induced apoptosis through calcineurin dephosphorylation of BAD. Science 284: 339-343

14. Yang E, Zha J, Jockel J, Boise LH, Thompson CB and Korsmeyer SJ (1995) $\mathrm{Bad}$, a heterodimeric partner for Bcl-XL and Bcl-2 displaces Bax and promotes cell death. Cell 80: 285-291

15. Zha J, Harada H, Yang E, Jockel J and Korsmeyer SJ (1996) Serine phosphorylation of death agonist BAD in response to survival factor results in binding to 14-3-3 not Bcl- $X_{L}$. Cell 87: 619-628

16. Zhou XM, Liu Y, Payne G, Lutz RJ and Chittenden T (2000) Growth factors inactivate the cell promoter BAD by phosphorylation of its $\mathrm{BH} 3$ domain on Ser 155. J. Biol. Chem. 275: 25046-25051

17. Harada H, Becknell B, Wilm M, Mann M, Huang LJ, Taylor SS, Scott JD and Korsmeyer SJ (1999) Phosphorylation and inactivation of BAD by mitochondria anchored protein kinase A. Mol. Cell 3: 413-422

18. Tan Y, Ruan H, Demeter MR and Comb MJ (1999) p90 (RSK) blocks badmediated cell death via a protein kinase C-dependent pathway. J. Biol. Chem. 274: 34859-34867

19. Datta SR, Dudek H, Tao X, Masters S, Fu H, Gotoh $Y$ and Greenberg ME (1997) Akt phosphorylation of BAD couples survival signals to the cell-intrinsic death mainOchinery. Cell 91: 231-241

20. Tan Y, Demeter MR, Ruan $H$ and Comb MJ (2000) BAD Ser-155 phosphorylation regulates $\mathrm{BAD} / \mathrm{Bcl}-\mathrm{X}_{\mathrm{L}}$ interaction and cell survival. J. Biol. Chem. 275: 25865-25869

21. Tabas I (2002) Consequences of cellular cholesterol accumulation: basic concepts and physiological implications. J. Clin. Invest. 110: 905-911

22. Ayllon V, Martinez AC, Garcia A, Cayla X and Rebollo A (2000) Protein phosphatase $1 \alpha$ is a Ras-activated Bad phosphatase that regulates interleukin2 deprivation-induced apoptosis. EMBO J. 19: 2237-2246

23. Basu S, Bayoumy S, Zhang Y, Lozano J and Kolesnick R (1998) BAD enables ceramide to signal apoptosis via Ras and Raf-1. J. Biol. Chem. 273: 3041930426

24. Xu SZ and Beech DJ (2001) TrpC1 is a membrane spanning subunit of store operated $\mathrm{Ca}^{2+}$ channels in native vascular smooth muscle cells. Circ. Res. 88: 84-87

25. Lockwish TP, Liu X, Sing BB, Jadlowiec J, Weiland S and Ambukar IS (2000) Assembly of Trp1 in a signaling complex associated with caveolin-scaffolding lipid raft domains. J. Biol. Chem. 275: 11934-11942

26. Emanuel HA, Hassel CA, Addis PB, Bergmann SD and Zavoral JH (1991) Plasma cholesterol oxidation products (oxysterols) in human subjects fed a meal rich in oxysterols. J. Food Sci. 56: 843-847
27. Vine DF, Mamo CL, Beilin LJ, Mori TA and Croft KD (1998) Dietary oxysterols are incorporated in plasma triglyceride-rich lipoproteins, increase their susceptibility to oxidation and increase aortic cholesterol concentration of rabbits. J. Lipid Res. 39: 1995-2004

28. Furuya Y, Lundmo P, Short AD, Gill DL and Isaacs JT (1994) The role of calcium, $\mathrm{pH}$, and cell proliferation in the programmed (apoptotic) death of androgen-independent prostatic cancer cells induced by thapsigargin. Cancer Res. 54: 6167-6175

29. Jiang S, Chow SC, Nicotera P and Orrenius S (1994) Intracellular Ca2+ signals activate apoptosis in thymocytes: studies using the $\mathrm{Ca}(2+)$-ATPase inhibitor thapsigargin. Exp. Cell Res. 212: 84-92

30. Tombal B, Weeraratna AT, Denmeade SR and Isaacs JT (2000) Thapsigargin induces a calmodulin/calcineurin-dependent apoptotic cascade responsible for the death of prostatic cancer cells. Prostate 43: 303-317

31. Pereira M, Millot JM, Sebille S and Manfait M (2002) Inhibitory effects of extracellular $\mathrm{Mg} 2+$ on intracellular $\mathrm{Ca} 2+$ dynamic changes and thapsigargininduced apoptosis in human cancer MCF7 cells. Mol. Cell. Biochem. 229: 163-171

32. Shibasaki $F$ and McKeon $F$ (1995) Calcineurin functions in $\mathrm{Ca}(2+)$-activated cell death in mammalian cells. J. Cell Biol. 131: 735-743

33. Shibasaki F, Kondo E, Akagi T and McKeon F (1997) Suppression of signalling through transcription factor NF-AT by interactions between calcineurin and Bcl2. Nature 386: 728-731

34. Chen CY and Faller DV (1995) Direction of p21ras-generated signals towards cell growth or apoptosis is determined by protein kinase $\mathrm{C}$ and $\mathrm{Bcl}-2$. Oncogene 11: $1487-1498$

35. Lizard G, Lemaire S, Monier S, Gueldry S, Néel D and Gambert P (1997) Induction of apoptosis and of interleukin-1beta secretion by 7 betahydroxycholesterol and 7-ketocholesterol: partial inhibition by Bcl-2 overexpression. FEBS Lett. 419: 276-280

36. Foster LJ, De Hoog CL and Mann M (2003) Unbiased quantitative proteomics of lipid rafts reveal high specificity for signaling factors. Proc. Natl. Acad. Sci. USA 100: 2813-5818

37. Aman MJ and Ravichandran KS (2000) A requirement for lipid rafts in B cell receptor induced $\mathrm{Ca}^{2+}$ flux. Curr. Biol. 10: 393-396

38. Yeh CG, His B and Faulk WP (1981) Propidium iodide as a nuclear marker in immunofluorescence. II. Use with cellular identification and viability studies. J. Immunol. Methods 43: 269-275

39. Merritt JE, McCarthy SA, Davies MPA and Moores KE (1990) Use of fluo-3 to measure cytosolic $\mathrm{Ca}^{2+}$ in platelets and neutrophils. Biochem. J. 269: 513-519

40. Miguet-Alfonsi C, Prunet C, Monier S, Bessède G, Lemaire-Ewing S, Berthier A, Ménétrier F, Néel D, Gambert P and Lizard G (2002) Analysis of oxidative processes and of myelin figures formation before and after the loss of mitochondrial transmembrane potential during $7 \beta$-hydroxycholesteroland 7 ketocholesterol induced apoptosis: comparison with various pro-apoptotic chemicals. Biochem. Pharm. 64: 527-541

41. Smith PK, Krohn RI, Hermanson GT, Mallia AK, Gartner FH, Provenzano MD, Fujimoto EK, Goeke NM, Olson BJ and Klenk DC (1985) Measurement of protein using bicinchonic acid. Anal. Biochem. 150: 76-85

42. Grazide S, Maestre N, Veldman RJ, Bezombes C, Maddens S, Levade T, Laurent G and Jaffrezou JP (2002) Ara-C6 and daunorubicin-induced recruitment of Lyn in sphingomyelinase-enriched membrane rafts. FASEB J. 16: $1685-1687$

43. Delmas D, Rébé $C$, Lacour S, Filomenko R, Athias A, Gambert $P$, CherkaouiMalki M, Jannin B, Dubrez-Dalloz L, Latruffe N and Solary E (2003) Resveratrol-induced apoptosis is associated with Fas redistribution in the rafts and the formation of a death-inducing signaling complex in colon cancer cells. J. Biol. Chem. 278: 41482-41490 